\title{
Differential Susceptibility of Xylella fastidiosa Strains to Synthetic Bactericidal Peptides
}

\author{
Aina Baró, Isabel Mora, Laura Montesinos, and Emilio Montesinos ${ }^{\dagger}$ \\ Institute of Food and Agricultural Technology-XaRTA-CIDSAV, University of Girona, C/ Maria Aurèlia Capmany 61, 17003 Girona, Spain \\ Accepted for publication 20 January 2020.
}

ABSTRACT

\begin{abstract}
The kinetics of cell inactivation and the susceptibility of Xylella fastidiosa subspecies fastidiosa, multiplex, and pauca to synthetic antimicrobial peptides from two libraries (CECMEL11 and CYCLO10) were studied. The bactericidal effect was dependent on the relative concentrations of peptide and bacterial cells, and was influenced by the diluent, either buffer or sap. The most bactericidal and lytic peptide was BP178, an enlarged derivative of the amphipathic cationic linear undecapeptide BP100. The maximum reduction in survivors after BP178 treatment occurred within the first 10 to $20 \mathrm{~min}$ of contact and at micromolar concentrations $(<10 \mu \mathrm{M})$, resulting in pore formation in cell membranes, abundant production of outer membrane vesicles, and lysis. A
\end{abstract}

threshold ratio of $10^{9}$ molecules of peptide per bacterial cell was estimated to be necessary to initiate cell inactivation. There was a differential susceptibility to BP178 among strains, with DD1 being the most resistant and CFBP 8173 the most susceptible. Moreover, strains showed a proportion of cells under the viable but nonculturable state, which was highly variable among strains. These findings may have implications for managing the diseases caused by $X$. fastidiosa.

Keywords: antimicrobial peptides, bactericidal activity, bacteriology, biochemistry and cell biology, disease control and pest management, $\mathrm{v}$-qPCR, viable but nonculturable state, Xylella fastidiosa
Xylem- and phloem-limited plant bacterial diseases, caused by phytoplasms, Candidatus Liberibacter, and Xylella fastidiosa, are among the most important threats limiting crop productivity worldwide (Kumari et al. 2019; Saponari et al. 2019; Wang et al. 2017). Diseases caused by $X$. fastidiosa produce leaf scorch and wilting symptoms, and sudden dead of infected plants, mainly due to interference with xylem vessel performance and sap flow (De Benedictis et al. 2017; Roper et al. 2007; Sicard et al. 2018). Although this pathogen is well established in several areas of the North and South American continents (e.g., Pierce's disease of grapevine and citrus variegated chlorosis) (Garcia et al. 2012; Purcell 2013), X. fastidiosa diseases have emerged in recent years as several outbreaks of considerable intensity and extension in Europe (e.g., Italy, France, and Spain), affecting mainly olive, almond, and also wild vegetation (Denancé et al. 2017; Olmo et al. 2017; Saponari et al. 2013).

The management of diseases caused by $X$. fastidiosa is currently based on the use of pathogen-free propagation plant material, quarantine and eradication measures, and vector control (Sicard et al. 2018). However, no cure for the disease exists up to now due to the lack of effective bactericides and the difficulties in accessing xylem vessels, where the pathogen establishes (EFSA Panel on Plant Health 2019; Kyrkou et al. 2018). Therefore, there is a need for new chemical compounds against $X$. fastidiosa, because current antibacterial compounds did not provide effective disease control (EFSA Panel on Plant Health 2019).

†Corresponding author: E. Montesinos; emilio.montesinos@udg.edu

Funding: This work was supported by grants from Ministerio de Ciencia, Innovación y Universidades of Spain (RTI Ref. 2018-099410-B-C21 and E-RTA INIA Ref. 2017-00004-C06-03), from the European Union H2020 programme (XFACTORS Ref. 727987), and from INTEROLIVO Growers Association (Ref. 041/ 18). A. Baró was recipient of a research grant from the Secretaria d'Universitats i Recerca, Departament d'Economia i Coneixement, Generalitat de Catalunya (Ref. 2018 FI B00334).

The author(s) declare no conflict of interest.

(c) 2020 The American Phytopathological Society
Antimicrobial peptides have been identified as potential candidates for plant disease control (Marcos et al. 2008; Montesinos 2007; Montesinos et al. 2012) and have a strong potential for the control of $X$. fastidiosa (Kuzina et al. 2006). Chimeras of naturally occurring or de novo synthetized peptide sequences have been obtained by structure-function approaches to improve their properties like antimicrobial activity, toxicity, protease susceptibility, and stability (Montesinos et al. 2012). Members of a CECMEL11 library of linear undecapeptides departing from cecropin A and melittin (Ferré et al. 2006) (e.g., peptide BP100) are active, both in vitro (lytic activity) and in planta at low micromolar concentrations, against several bacterial plant pathogens, like Erwinia amylovora, Pseudomonas syringae pathovars, Xanthomonas-vesicatoria, Xanthomonas arboricola pv. pruni, Xanthomonas fragariae, and phytoplasms (Badosa et al. 2007; Rufo et al. 2017). Based on these interesting properties, several derivatives of BP100 have been developed to find new biological properties (arylhistidines, peptidotriazoles, and carbopeptides) (Güell et al. 2011, 2012; Ng-Choi et al. 2014), or for plant expression (Badosa et al. 2013). Another library, the CYCLO10, consisting of de novo designed cyclo-decapeptides was developed (Monroc et al. 2006), and peptide BPC194 and several histidine and lipopeptide derivatives showed interesting bactericidal properties (Vilà et al. 2016).

Studies on inhibition of $X$. fastidiosa by antimicrobial peptides have received little attention in the past, probably due to the difficulties of working with this fastidious bacterium. Though, a few reports have provided the minimal inhibitory concentration (MIC) of growth for cecropin/magainin derivatives ( $\mathrm{Li}$ and Gray 2003), cecropins A/B (Andersen et al. 2004), gomosin (Fogaça et al. 2010), indolicidin and dermaseptin derivatives (Kuzina et al. 2006), and radicinin (Aldrich et al. 2015). However, it was not determined if the effect observed was simply bacteriostatic or bactericidal. To assess the bactericidal activity, a "killing assay" (contact test) has to be performed (Lambert 2004), as it is done with several bacterial pathogens of clinical, food, and water interest (Abdelbaqi et al. 2016; Pini et al. 2005). In addition, there is a need to analyze doseresponse relationships and to know if there are differences in susceptibility to peptides among strains of $X$. fastidiosa. 
The aims of the present work were (i) to screen lead peptides from CECMEL11 and CYCLO10 libraries for their bactericidal activity against $X$. fastidiosa, (ii) to relate peptide activity with cell damage at ultrastructural level, (iii) to study the kinetics of cell survival and dose-effect relationships, and (iv) to analyze the effect of the most active peptide, BP178, on the viability and culturability of different $X$. fastidiosa strains.

\section{MATERIALS AND METHODS}

Bacterial strains and growth conditions. Several strains of $X$. fastidiosa were used (Table 1) depending on the experiment. All bacteria were stored in Pierce disease (PD2) (Davis et al. 1980) broth supplemented with glycerol $(30 \%)$ and maintained at $-80^{\circ} \mathrm{C}$. When required, strains were cultured in buffered charcoal yeast extract (Coletta-Filho and Machado 2003) and colonies scrapped from the agar surface after growing for 5 to 7 days at $28^{\circ} \mathrm{C}$. The cell material was suspended in sterile succinate citrate phosphate (SCP) buffer (EPPO 2018) to obtain a suspension of an optical density (OD) at $600 \mathrm{~nm}$ (Spectro Direct, Tintometer GmbH, Lovibond Water Testing, Germany) of 0.3 to 0.35 (depending on X. fastidiosa strain), corresponding to $10^{8} \mathrm{CFU} / \mathrm{ml}$. Previously, standard curves relating OD to cell concentration were obtained for all strains.

Peptides. Three linear peptides from the CECMEL11 library and one cyclic peptide from the CYCLO10 library were used. Peptides BP100 and BP15 were linear undecapeptides consisting of cecropin A (amino acids from 1 to 7 ) and melittin (amino acids from 2 to 9) hybrids (Ferré et al. 2006). Peptide BP178 is a derivative from BP100 (Badosa et al. 2013). All of them were synthesized in the Laboratory of Organic Chemistry from the University of Girona (LIPPSO) by means of solid-phase synthesis methods. Cyclic peptide BPC194 (Monroc et al. 2006) was purchased from Caslo Laboratory ApS (Lyngby, Denmark). Lyophilized peptides were solubilized in sterile Milli-Q water to a stock concentration of $2 \mathrm{mM}$ and filter sterilized through a $0.22-\mu \mathrm{m}$-pore-size filter. Dilutions of the stock solution were made to obtain the desired final concentrations. Characteristics of the peptides are shown in Table 2.

General conditions for the contact test. The activity of the antimicrobial peptides was tested by a contact exposure test (Russell et al. 1982). Twenty microliters of the corresponding peptide dilution was mixed in a multiwell plate with $180 \mu \mathrm{l}$ of a $X$. fastidiosa suspension (final cell concentration of $10^{6}, 10^{7}$, or $10^{8}$
$\mathrm{CFU} / \mathrm{ml}$, depending on the assay) to a total volume of $200 \mu \mathrm{l}$. In all experiments, three replicates for each concentration, peptide, and strain were used, and a nontreated control was also included. Multiwell plates were incubated at $25^{\circ} \mathrm{C}$ and samples were taken at the desired contact time. Depending on the experiment, bactericidal activity was evaluated through quantification of (i) culturable cells by plate counting and/or (ii) viable cells by viable quantitative PCR (v-qPCR) (described below). Plate counting was performed by plating $20 \mu \mathrm{l}$ of 10-fold dilutions on PD2 agar plate, and colony forming units were determined after the incubation of Petri plates at $28^{\circ} \mathrm{C}$ for 7 to 21 days. To quantify viable cells, $200 \mu \mathrm{l}$ of each bacterial suspension was treated with PEMAX (GenIUL, Terrassa, Spain) at $7.5 \mu \mathrm{M}$ and after DNA extraction (GeneJET Genomic DNA Purification Kit, Thermo Fisher Scientific, U.S.A.), DNA samples were analyzed in duplicate by a TaqMan-based qPCR assay using the target-specific XF16S-3 primer pair (reverse GTAGGA GTCTGGACCGTGTCTC, forward CGGCAGCACGTTGGTAGTAA, probe FAM/-CATGGGTGGCGAGTGGC-/TAMRA).

Standard curves were made by preparing 10-fold serial dilutions of a homogeneous cell suspension of $10^{8} \mathrm{CFU} / \mathrm{ml}$, until $10^{2} \mathrm{CFU} / \mathrm{ml}$, obtained by scraping the surface of an actively growing Petri plate culture. Then, culturable cells, assessed by plate counting, and $\mathrm{C}_{\mathrm{T}}$ values, determined by v-qPCR as described previously, were used to calculate a calibration curve. The amount of viable cells, expressed as $\log _{10} \mathrm{CFU} / \mathrm{ml}$, was obtained by interpolating the $\mathrm{C}_{\mathrm{T}}$ values from each sample against the respective standard curve for each strain.

Bactericidal activity of lead peptides. The bactericidal activity of four lead peptides (BPC194, BP15, BP100, and BP178) was tested against cell suspensions of two strains of $X$. fastidiosa subsp. fastidiosa (Temecula and LMG 17159) and one strain of $X$. fastidiosa subsp. pauca (DD1), adjusted to $10^{7} \mathrm{CFU} / \mathrm{ml}$. A $3 \mathrm{~h}$ contact test was performed at final peptide concentrations of 1,10 , and $50 \mu \mathrm{M}$. Culturable cells were quantified by plate counting as described previously.

Effect of the diluent solution or sap on the activity of peptide BP178. The effect of SCP buffer, phosphate buffered saline (PBS) (EPPO 2018), and xylem sap (undiluted and half diluted in distilled water) on the antibacterial activity of BP178 was studied. SCP buffer was composed of $1.0 \mathrm{~g}$ of trisodium citrate, $1.0 \mathrm{~g}$ of disodium succinate, $1.5 \mathrm{~g}$ of dipotassium phosphate, and $1.0 \mathrm{~g}$ of potassium phosphate per 1.0 liter of distilled water. PBS was

TABLE 1. Strains of Xylella fastidiosa used in the present work

\begin{tabular}{lllll}
\hline Strain & \multicolumn{1}{c}{ Subspecies } & \multicolumn{1}{c}{ Source $^{\mathrm{a}}$} & \multicolumn{1}{c}{ Origin } & \multicolumn{1}{c}{ Reference } \\
\hline DD1 (De Donno) & X. fastidiosa subsp. pauca & CNR-Bari & Olive, Apulia (Italy) & Saponari et al. 2017 \\
Temecula (ATCC 700964) & X. fastidiosa subsp. fastidiosa & ATCC & Grapevine, Riverside, California (U.S.A.) & Rodrigues et al. 2003 \\
IVIA 5235.4 & X. fastidiosa subsp. fastidiosa & IVIA & Cherry, Mallorca (Spain) & Olmo et al. 2017 \\
IVIA 5387.2 & X. fastidiosa subsp. fastidiosa & IVIA & Almond, Mallorca (Spain) & Giampetruzzi et al. 2019 \\
IVIA 5901.2 & X. fastidiosa subsp. multiplex & IVIA & Almond, Alicante (Spain) & EPPO 2018 \\
CFBP 8430 & X. fastidiosa subsp. multiplex & CFBP & NA $^{\mathrm{b}}$ & \\
CFBP 8173 & X. fastidiosa subsp. multiplex & CFBP & Prunus, Georgia (U.S.A.) & Schaad et al. 2004 \\
LMG 17159 & $X$. fastidiosa subsp. fastidiosa & LMG & Grapevine, Florida (U.S.A.) & NA $^{\mathrm{b}}$ \\
\hline
\end{tabular}

a CNR-Bari, Consiglio Nazionale delle Ricerche; ATCC, American Type Culture Collection; IVIA, Instituto Valenciano de Investigaciones Agrarias; CFBP, International Center for Bacterial Resources, INRA; and LMG, Laboratory of Microbiology from Ghent University.

b Not accounted.

TABLE 2. Characteristics of the antimicrobial peptides used in this work, and reported activity against representative plant pathogenic bacteria

\begin{tabular}{|c|c|c|c|c|c|}
\hline \multirow[b]{2}{*}{ Peptide } & \multirow[b]{2}{*}{ Sequence } & \multicolumn{3}{|c|}{$\operatorname{MIC}(\mu \mathrm{M})^{\mathrm{a}}$} & \multirow[b]{2}{*}{ Reference } \\
\hline & & $X a v$ & Pss & $E a$ & \\
\hline BP15 & KKLFKKILKVL-NH ${ }_{2}$ & $12.0-15.0$ & $2.0-5.0$ & $5.0-7.0$ & Ferré et al. 2006 \\
\hline BP100 & H-KKLFKKILKYL-NH 2 & $5.0-7.5$ & $2.5-5.0$ & $2.5-5.0$ & Badosa et al. 2007 \\
\hline BP178 & KKLFKKILKYL-AGPA-GIGKFLHSAK-KDEL-OH & $2.5-5.0$ & $2.5-5.0$ & $2.5-5.0$ & Badosa et al. 2013 \\
\hline BPC194 & $\mathrm{c}(\mathrm{KKLKKFKKLQ)}$ & $3.1-6.2$ & $3.1-6.2$ & $6.2-12.5$ & Monroc et al. 2006 \\
\hline
\end{tabular}

${ }^{a}$ Minimal inhibitory concentration. Xav, Xanthomonas arboricola pv. vesicatoria; Pss, Pseudomonas syringae pv. syringae; Ea, Erwinia amylovora. 
composed of $8.0 \mathrm{~g}$ of sodium chloride, $0.2 \mathrm{~g}$ of potassium chloride, $1.15 \mathrm{~g}$ of disodium phosphate, $0.2 \mathrm{~g}$ of potassium phosphate per 1.0 liter of distilled water. The above buffers were sterilized with autoclave. Xylem sap was obtained from grapevine cultivar Carinyena by pruning six plants before bud break and collecting sap bleeding directly at the cutting edge of the shoots. Sap was sterilized by filtration and preserved at $-80^{\circ} \mathrm{C}$ until use. A cell suspension of $X$. fastidiosa subsp. fastidiosa Temecula adjusted to $10^{7} \mathrm{CFU} / \mathrm{ml}$ was prepared, and $180 \mu \mathrm{l}$ was centrifuged for $10 \mathrm{~min}$ at $13,000 \mathrm{rpm}$ to collect all the cells. The pelleted cells were resuspended with the same volume of the appropriate solution (SCP, PBS, sap, or diluted sap), and $20 \mu$ lof the peptide dilutions was added to a final volume of $200 \mu \mathrm{l}$. A $3 \mathrm{~h}$ contact test was performed at final peptide concentrations of $1.5,3.1,12.5,50,100$, and $150 \mu \mathrm{M}$. After the incubation period, viable cells were quantified by v-qPCR, and the proportion of viable cells reduction $\left(\mathrm{N}_{0} / \mathrm{N}_{t}\right)$ was used as a measure of the peptide activity. $\mathrm{N}_{0}$ and $\mathrm{N}_{\mathrm{t}}$ were the initial and final concentration of viable cells, respectively. The experiment was performed two times.

Death kinetics and dose-response relationships. The effect of BP178 on the survival (culturable cells) of X. fastidiosa subsp. fastidiosa Temecula, X. fastidiosa subsp. multiplex IVIA 5901.2, and $X$. fastidiosa subsp. pauca DD1 was tested over time. Peptide concentrations tested were 5, 10, 25, and $50 \mu \mathrm{M}$. The initial cell concentration was $10^{7} \mathrm{CFU} / \mathrm{ml}$, and sampling was performed at different times depending on the experiment (from 0 to $180 \mathrm{~min}$ ). Plate counting was performed as described above and the proportion of survivors reduction $\left(\mathrm{N}_{0} / \mathrm{N}_{\mathrm{t}}\right)$ was used as a measure of the activity of peptide. The experiment was performed two times, one for the kinetics and another for the effect of the concentration at 120 or 180 min contact time.

Alteration of cell membrane integrity by the antimicrobial peptides. The cell envelope integrity of $X$. fastidiosa subsp. fastidiosa Temecula and $X$. fastidiosa subsp. pauca DD1 after peptide treatment was observed by transmission electron microscopes (TEM), using samples taken from the previously described experiments. After $3 \mathrm{~h}$ of contact exposure to BP178 at different concentrations (i.e., 5, 20, and $100 \mu \mathrm{M}$ ), cells were harvested by centrifugation at $10,000 \times g$ for $10 \mathrm{~min}$. For preservation of the structure, cells were fixed with glutaraldehyde $(2.5 \%)$ in sodium cacodylate buffer $(0.1 \mathrm{M}, \mathrm{pH} 7.4)$ for $4 \mathrm{~h}$ at $4^{\circ} \mathrm{C}$. Fixed pellets were washed in sodium cacodylate buffer $(0.1 \mathrm{M}, \mathrm{pH} 7.4)$ two times during $30 \mathrm{~min}$ at $4{ }^{\circ} \mathrm{C}$, and stored at the same temperature until postfixing. Postfixation was performed in $1 \% \quad \mathrm{OsO}_{4}$ osmium tetraoxide in sodium cacodylate buffer $(0.1 \mathrm{M}, \mathrm{pH} 7.4)$ for $3 \mathrm{~h}$ at room temperature. Then, the samples were washed again in sodium

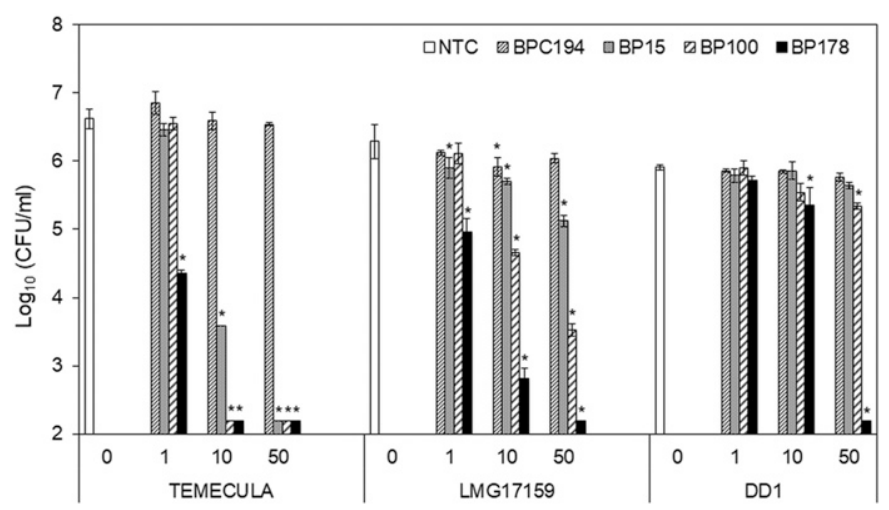

Fig. 1. Effect of peptides BPC194, BP15, BP100, and BP178 on survival (culturable cells) of Xylella fastidiosa subsp. fastidiosa strains Temecula and LMG 17159, and X. fastidiosa subsp. pauca DD1. A contact test was performed at 0 (NTC, nontreated control), 1,10 , or $50 \mu \mathrm{M}$ peptide concentrations. Values are the means of three replicates, and error bars represent the standard deviation of the mean. Asterisks indicate treatments significantly different from NTC within each strain according to Tukey's test $(P<0.05)$. cacodylate buffer and dehydrated in ethanol series. The inclusion step in epoxy resin was performed at room temperature using a Noria shaker. Then, ultra-thin sections of 60 to $80 \mathrm{~nm}$ were obtained. Contrast of sections was performed with uranium acetate $2 \%$ and then lead citrate (Reynolds 1963). The samples were observed either with a Zeiss EM-910 or with a JEOL JEEM1400 transmission electron microscope. TEM micrographs were taken and used to determine the frequency of live, affected, and lysed cells for the nontreated control and for cells exposed to $20 \mu \mathrm{M}$ BP178. Live cells were considered when the ultrastructure did not show signs of damage as in most cells of the nontreated control; affected cells showed cytoplasm retraction or intracellular condensation bodies; and lysed cells showed envelope anomalies (e.g., membrane pores and outer membrane vesicles) or free cell membrane material.

Effect of BP178 on viable and culturable cells. Four contact test experiments with BP178 were performed as described above against seven $X$. fastidiosa strains (Table 1). The experiments were performed by combining cell concentration at $10^{7}$ or $10^{8} \mathrm{CFU} / \mathrm{ml}$ with peptide concentration at 10 or $25 \mu \mathrm{M}$. After $3 \mathrm{~h}$ incubation, culturable (plate counting) and viable (v-qPCR) cells were quantified as described above, and the percentage of survival $\left(100 \times \mathrm{N}_{\mathrm{t}} / \mathrm{N}_{0}\right)$ was used as a measure of the strain susceptibility to the peptide.

Data analysis. Shapiro-Wilk and Leven's tests were performed to assess data normality and homoscedasticity. To test the significance of the effect of strain, peptide and peptide concentration in the experiments, two-way analysis of variance was performed. Means of $\log _{10}$ survivors, reduction in survivors, or percentage of survival were separated according to the Tukey's test at a $P$ value of $\leq 0.05$.

\section{RESULTS}

Bactericidal activity of peptides. The cyclic decapeptide BPC194, the CECMEL11 peptides BP15 and BP100, and the BP100 derivative peptide, BP178, were assessed for their bactericidal activity against three strains of $X$. fastidiosa, at three peptide concentrations (Fig. 1). Survival was significantly affected by the type and dose of peptide. However, the effect of the peptide was dependent on the strain $(P<0.001)$. The Temecula strain significantly decreased culturability by peptides BP178, BP100, and BP15 at 10 and $50 \mu \mathrm{M}$, followed by LMG 17159 which also undergo a reduction of culturable cells after the contact test with these three peptides. The DD1 strain was susceptible to peptide BP178 at 10 and $50 \mu \mathrm{M}$, but only to BP100 at $50 \mu \mathrm{M}$. Globally, the most active peptide was BP178, followed by BP100 and BP15. No significant activity was observed for peptide BPC194.

Effect of the diluent solution or sap on the activity of BP178. The effect of different buffer solutions or plant sap on the activity of BP178 against $X$. fastidiosa subsp. fastidiosa Temecula is shown in Figure 2. The diluent had a significant effect on the reduction of viable cells after exposure to peptide BP178 at all concentrations assessed $(P<0.001)$. BP178 had higher activity when cells were suspended in buffer solutions than in sap. At concentrations above $50 \mu \mathrm{M}$, the reduction in viable cells was of 1.5 to $3 \log$ when using buffer solutions, and of 0.3 to $1 \log$ when cells were suspended in sap (diluted or undiluted). SCP buffer allowed the highest activity of the BP178 peptide.

Lytic effects of peptide BP178 on $\boldsymbol{X}$. fastidiosa. BP178 peptide had clearly lytic effects on Temecula and DD1 strains as it is shown by TEM micrographs (Figs. 3 and 4). The untreated control cells showed the typical cristate ultrastructure of a well-organized cell envelope, containing the outer membrane (OM) and cytoplasmic membrane (Figs. 3A and B and 4B). In the case of Temecula strain, peptide treatment at 5 and $20 \mu \mathrm{M}$ already resulted in strong cell damage (Fig. 3C and E) with cell lysis and abundant production of typical outer membrane vesicles (OMV) observed as spheroid particles ranging in size from approximately 20 to $250 \mathrm{~nm}$, produced through the blebbing and pinching off of portions of the OM 


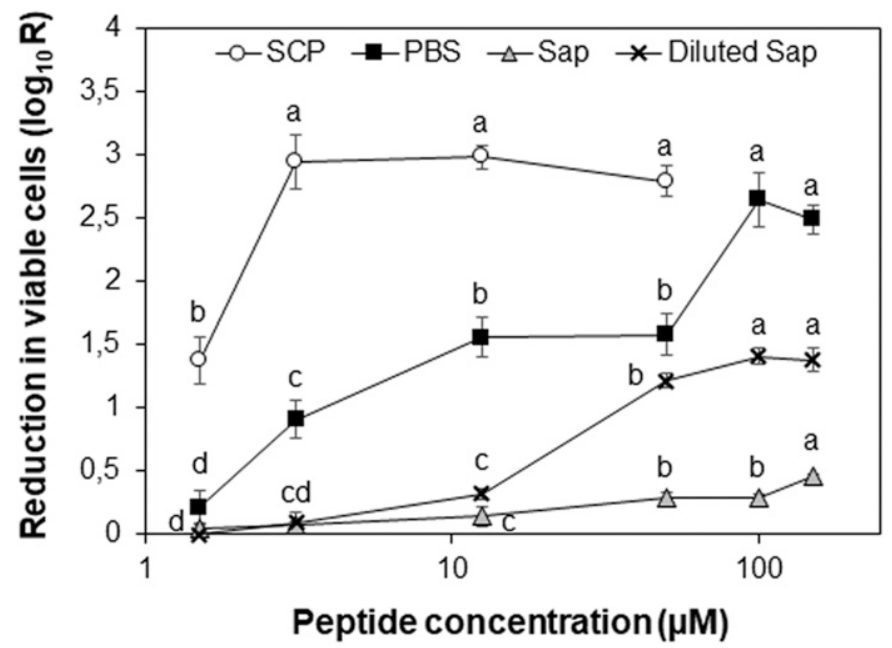

Fig. 2. Effect of the diluent solution on the activity of BP178 against Xylella fastidiosa subsp. fastidiosa Temecula. Different peptide concentrations and diluent solutions were evaluated. SCP, succinate citrate phosphate buffer; PBS, phosphate buffered saline; Sap, xylem sap from Vitis sp.; and Diluted sap, half diluted sap. Values are the means of three replicates, and error bars represent the standard deviation of the mean. Different letters within the same diluent indicate significant differences between peptide concentrations according to Tukey's test $(P<0.05)$.
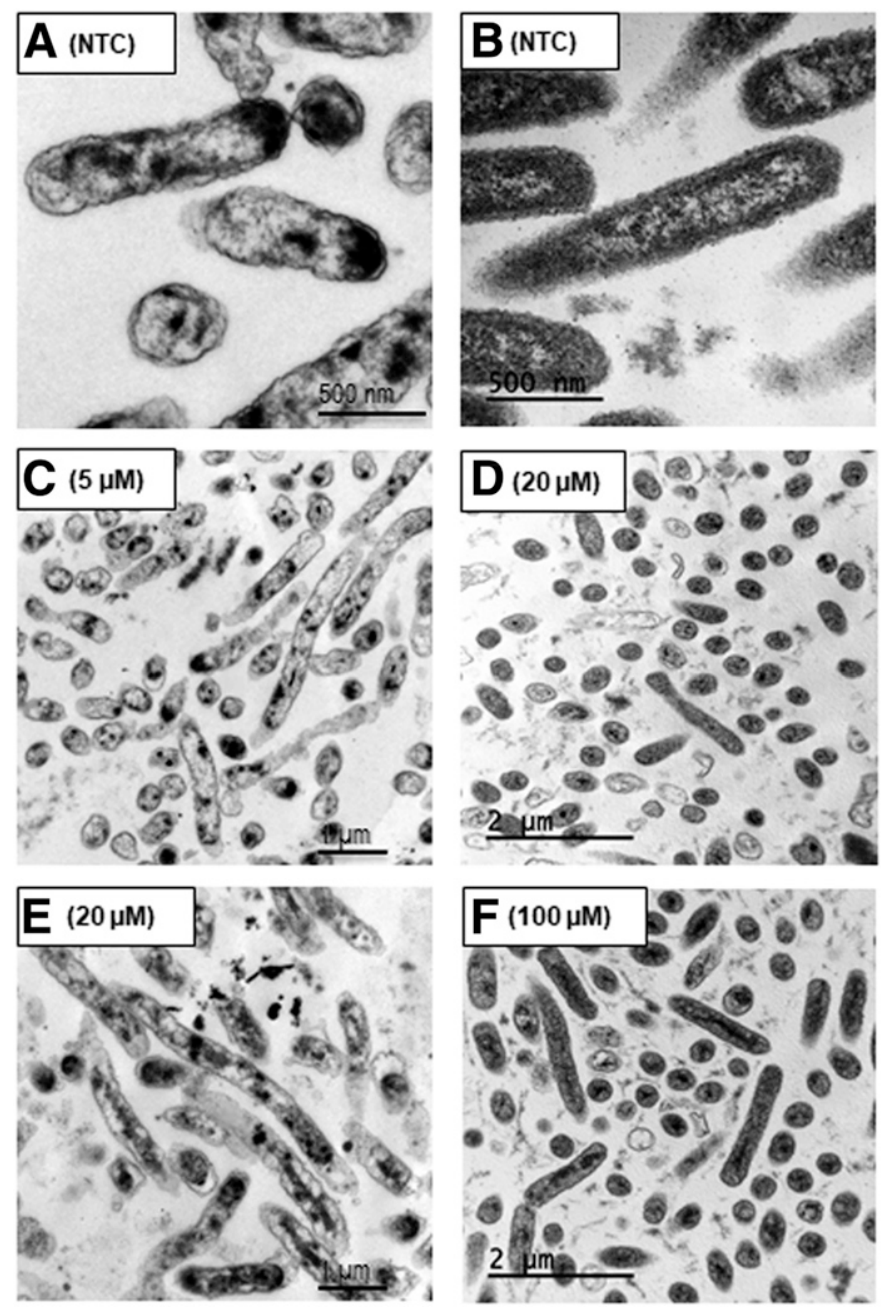

Fig. 3. Ultrastructure of Xylella fastidiosa subsp. fastidiosa Temecula and $X$. fastidiosa subsp. pauca DD1 after exposure to peptide BP178 at different concentrations. A, C, and E, Temecula strain; and B, D, and F, DD1 strain. Peptide concentrations are shown in brackets.
(Fig. 4E). Peptide treatment also resulted in pore formation in cell membranes (Fig. 4C and D). Moreover, condensation of intracellular material and presence of free cell membranes were observed (Fig. 4F). On the contrary, DD1 strain showed lower cell lysis than Temecula strain even at 20 or $100 \mu \mathrm{M}$ (Fig. 3D and F). Despite this, cells showed frequently intracellular material condensation at $100 \mu \mathrm{M}$ (Fig. 3F). Untreated controls of DD1 showed the presence of an exopolysaccharide barrier around the cells, observed as a lighter halo, which was not detected in the case of Temecula cells (Fig. 4A). Based on their ultrastructure, cells from both strains were classified as live (normal structure), affected (cytoplasm retraction or presence of intracellular condensation bodies), or lysed cells (empty or strongly disorganized with membrane pores or OMVs). Temecula and DD1 strains significantly differed in their susceptibility to the lytic effect of peptide BP178 $(P<0.001)$. As shown in Figure 5, BP178 at $20 \mu \mathrm{M}$ had a strong and significant effect in decreasing live cells and increasing the frequency of affected and lysed cells in Temecula strain. However, in DD1 strain there was a slight but significant effect in increasing the frequency of affected cells and no significant effect was observed in the frequency of live and lysed cells.

Time-course of cell survival upon peptide treatment. The time-course of cells survival was studied as culturable cells at four BP178 peptide concentrations (Fig. 6). The death kinetics showed two stages, a fast first stage (10 to $20 \mathrm{~min})$ followed by a second
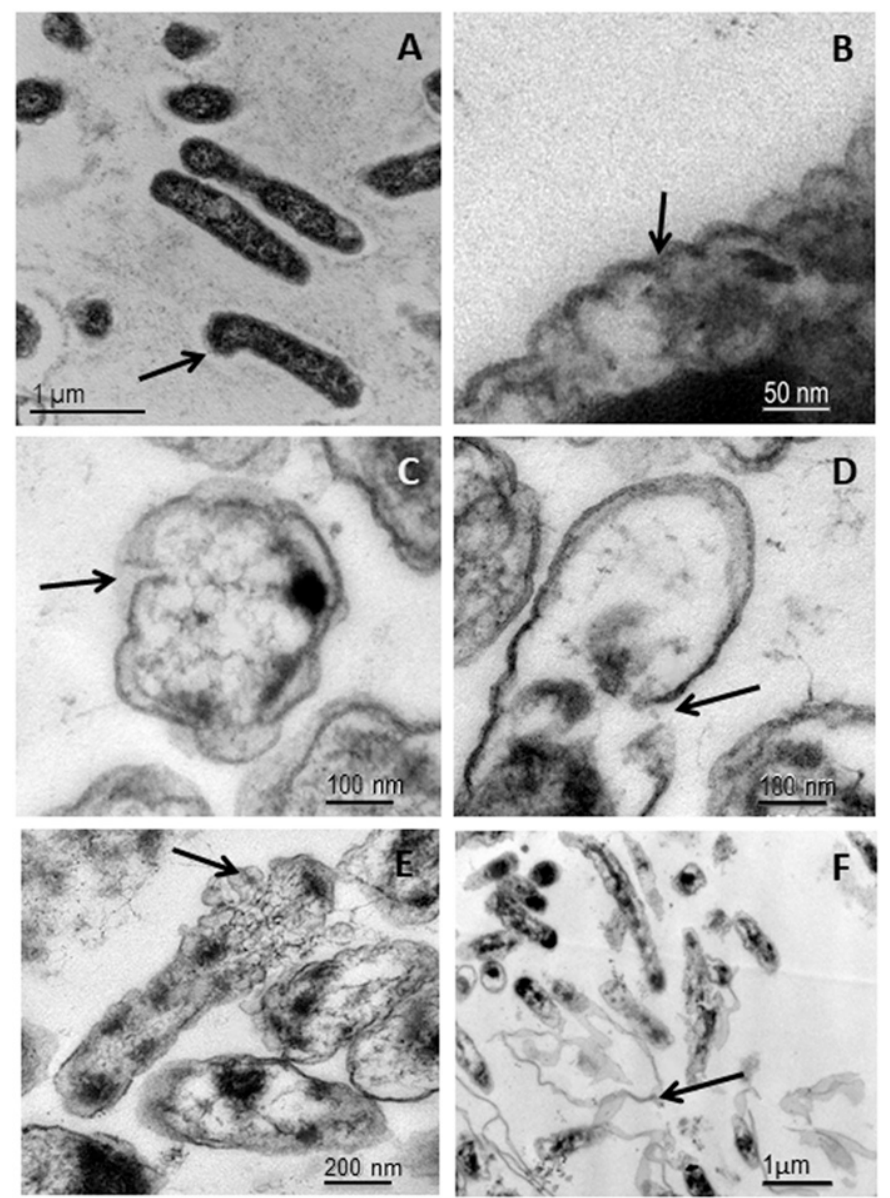

Fig. 4. Relevant structures of Xylella fastidiosa observed with transmission electron microscopes (indicated with arrows). A, Presence of an exomucopolysaccharide envelope in strain DD1; B, cristate structure of the cell wall; $\mathbf{C}$ and $\mathbf{D}$, initial stages of pore formation in the cell membranes by peptide BP178; E, burst of cell membranes with abundant outer membrane vesicles in Temecula strain; and F, rest of cell membranes and presence of condensed intracellular material after BP178 treatment at high concentrations. 
stage consisting of a plateau of maximal survival reduction. Reduction in survivors was significantly affected by the peptide concentration in Temecula $(P<0.001)$ and IVIA $5901.2(P<$ $0.001)$; in the case of DD1 strain, this effect was lower although significant $(P<0.001)$. Low peptide concentrations $(5$ and $10 \mu \mathrm{M})$, reduced $2 \log$ survival in Temecula strain, only $1 \log$ in IVIA 5901.2, but much less in DD1 strain. High peptide concentrations $(25$ and $50 \mu \mathrm{M})$, reduced 4 to $6 \log$ survival in Temecula strain, 2 to 4 $\log$ in IVIA 5901.2 and less than $1 \log$ in DD1.

Dose-effect relationships. The relationship between the reduction in survivors as culturable cells, at several peptide concentrations, is shown in Figure 7. There were significant differences in this parameter between strains $(P<0.001)$, with Temecula strain showing the highest reduction, slightly followed by IVIA 5901.2. X. fastidiosa subsp. pauca strain DD1 was the least susceptible among the three strains studied. Reduction in survivors showed a direct relationship to peptide concentration in all strains, but a hyperbolic pattern (typical saturation kinetics) was observed. No significant increase of bactericidal effect was evidenced at peptide concentrations higher than $25 \mu \mathrm{M}$. In addition, cells survival (culturable cells) at different peptide and initial cell concentrations obtained from several contact test experiments (data from Figs. 1, 6, and 7) were used to calculate the ratio between the number of molecules of BP178 per cell. The plot of the reduction in survivors against the ratio is shown in Figure 8. Interestingly, a minimal threshold ratio to have a bactericidal effect was observed at $9 \log _{10}$ number of molecules of BP178 per cell.

Effect of BP178 treatment on viability and culturability of cells. The effect of the treatment with peptide BP178 on cell viability (v-qPCR) and culturability (plate counting) was studied in seven strains of $X$. fastidiosa. The experiment was repeated but, at two different peptide and cell concentrations (Fig. 9). It was observed that there were significant differences in survival (culturable and viable cells) among strains $(P<0.001)$. For the strains of the subspecies fastidiosa (Temecula, IVIA 5235.4, and IVIA 5387.2) and multiplex (IVIA 5901.2, CFBP 8173, and CFBP 8430) there was no particular pattern in the effect of peptide BP178 on survival associated to the subspecies. The most susceptible strain was CFBP 8173 with a reduction in survival to $\log _{10}$ of -3 (log reduction in survivors of 5), and the least susceptible strain was DD1 with $\log _{10}$ of 0 (log reduction in survivors of 2 ) at $25 \mu \mathrm{M}$ of peptide and $10^{7} \mathrm{CFU} / \mathrm{ml}$ (Fig. 9). This pattern was observed in the four experiments performed.

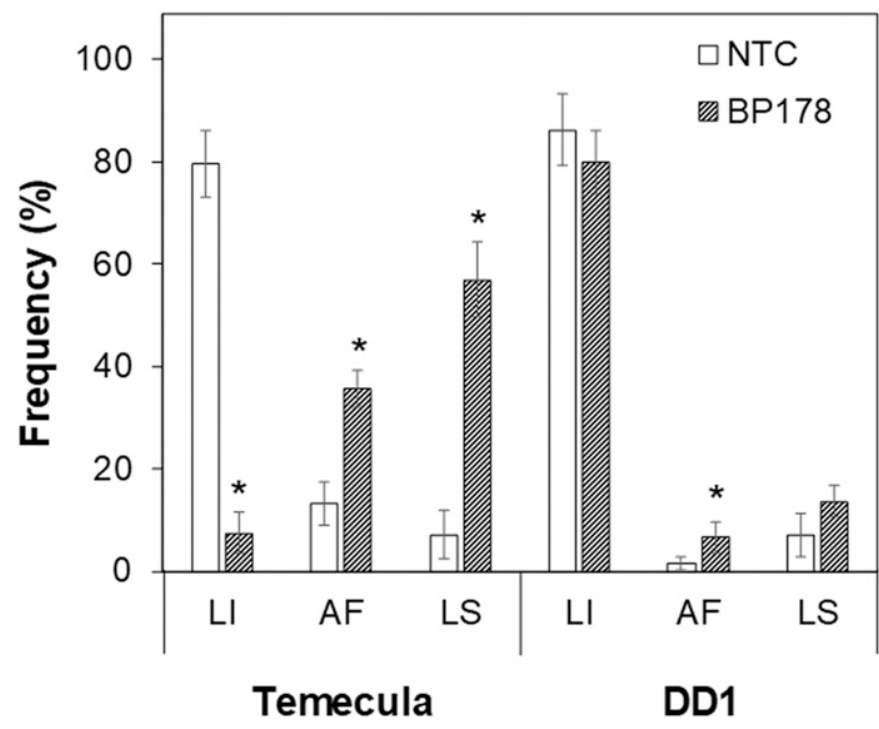

Fig. 5. Effect of BP178 peptide on the frequency of live, affected, and lysed cells in Temecula and DD1 strains compared with a nontreated control (NTC). Data correspond to transmission electron microscope pictures taken in the same experiments of Figures 3 and 4. Peptide concentration was $20 \mu \mathrm{M}$. Values are the means of three replicates, and error bars represent the standard deviation of the mean. Asterisks indicate significant differences between BP178 treatment and NTC according to Tukey's test $(P<0.05)$.
By comparing $\mathrm{v}-\mathrm{qPCR}$ and plate counting for each strain, it was observed that after the peptide treatment, as expected, more viable than culturable cells were observed in all strains $(P<0.001)$. This difference can be attributed to the development of a viable but nonculturable state (VBNC). The strains response to BP178 in terms of VBNC levels was very different. For example, in DD1 practically all viable cells were culturable at the two cell and peptide concentrations studied. However, in other strains most viable cells were nonculturable (IVIA 5235.4 at $10^{7} \mathrm{CFU} / \mathrm{ml}$ and 10 and $25 \mu \mathrm{M}$ of BP178; IVIA 5901.2 at $10^{7} \mathrm{CFU} / \mathrm{ml}$ and $25 \mu \mathrm{M}$ of BP178).

\section{DISCUSSION}

In the present study we used a contact test ("killing assay") for the assessment of the kinetics of viable/culturable cells during

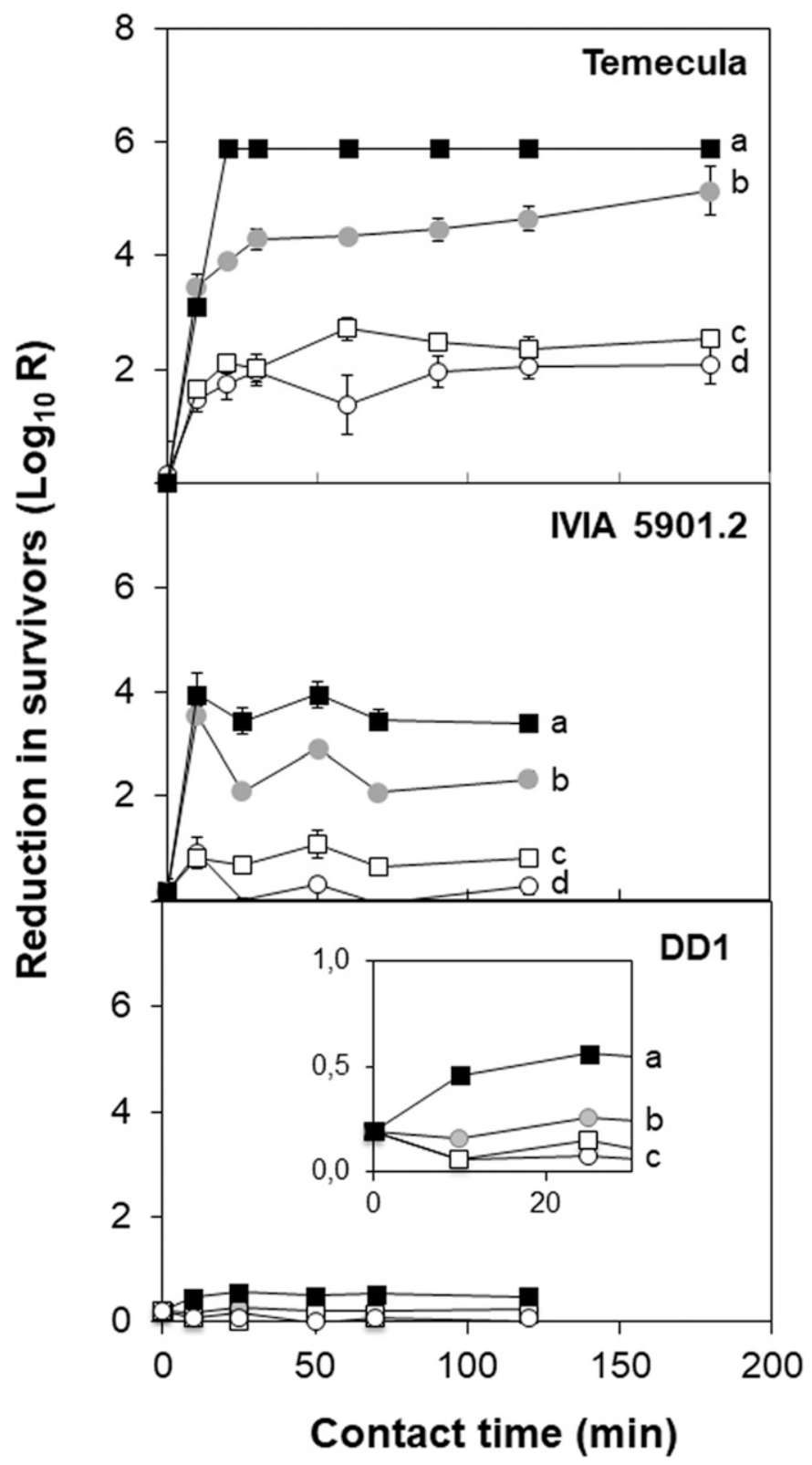

Fig. 6. Kinetics of survival of Xylella fastidiosa subsp. fastidiosa Temecula, $X$. fastidiosa subsp. multiplex IVIA 5901.2, and X. fastidiosa subsp. pauca DD1 in the presence of peptide BP178 at different concentrations. Concentrations of peptide were $5 \mu \mathrm{M}$ (white circle), $10 \mu \mathrm{M}$ (white square), $25 \mu \mathrm{M}$ (gray circle), and $50 \mu \mathrm{M}$ (black square). Values are the means of three replicates, and error bars represent the standard deviation of the mean. Different letters within the same strain panel indicate significant differences between peptide concentrations in survival at the end time points, according to Tukey's test $(P<0.05)$. 
the exposure to synthetic antimicrobial peptides, and we evaluated the bactericidal effect of peptides on different $X$. fastidiosa strains. Most studies on the activity of antimicrobials against $X$. fastidiosa used growth inhibition assays to determine the MIC (Aldrich et al. 2015; Andersen et al. 2004; Fogaça et al. 2010; Kuzina et al. 2006; Li and Gray 2003). However, in growth inhibition assays, the antimicrobial agent is continuously in contact with the microorganism cells and the inhibitory activity cannot be distinguished between biostatic and biocidal effects (Lambert 2004).

The strongest bactericidal activity among the tested CECMEL11 and CYCLO10 leads or derivative peptides was observed in BP178. Peptide BP178 was originally designed as a derivative from BP100 for plant expression and it has been successfully produced in rice seed endosperm (Montesinos et al. 2017). Its sequence included an $\mathrm{N}$-terminal ER retention signal (KDEL) and a hinge (AGPA) to separate BP100 from a sequence of magainin (GIGKFLHSAK) (Badosa et al. 2013).

BP178 is more active in SCP than in PBS and grapevine xylem sap. As in other amphipathic peptides, its antimicrobial activity is affected by the net charge, and the $\mathrm{pH}$ and salts composition of the diluent (Nguyen et al. 2011). In particular, salts decrease activity while low $\mathrm{pH}$ moderately increase it, as in cecropin P1 and magainin 1 (Kacprzyk et al. 2007; Schwab et al. 1999), but this effect depends on the target microorganism (Andersen et al. 2004; Lee et al. 1997). Total salts contents in SCP buffer is lower ( $4.5 \mathrm{~g} /$ liter) than in PBS buffer (9.5 g/liter), and this is in agreement with the above mentioned report. Unfortunately, we did not measure salts contents in the grapevine xylem sap used for the experiments, but the fact that upon dilution peptide activity have increased indicates that the inhibitory effect is probably due to its solutes concentration. The total solute contents in xylem sap of most plants range from 0.5 to $20 \mathrm{~g} /$ liter and the main components in grapevine have been reported to be inorganic ions, amino acids (mainly glutamine) and organic acids (Andersen and Brodbeck 1989; Lima et al. 2017). Because xylem sap composition strongly changes with plant species, phenological stage, and environmental conditions (Tyree and Zimmermann 2002), the activity of peptide BP178 against $X$. fastidios $a$ in plant hosts may have limitations under certain conditions, but could be favored in others.
The bactericidal activity of peptide BP178 on X. fastidiosa was due to lytic effects. The mechanism of action of amphipathic cationic peptides, like CECMEL11 (e.g., BP100 and BP178), is based on its interaction with lipid components of the cell membranes, leading to membrane permeabilization or disorganization with the consequence of cell lysis (Nguyen et al. 2011). We have shown that cells of $X$. fastidiosa subsp. fastidiosa Temecula and $X$. fastidiosa subsp. pauca strain DD1, after contact with the peptide, showed strong damage in the cell envelope as was observed by TEM ultrastructural analysis. This effect was observed in the Temecula strain at low peptide concentration, affecting both outer and inner membranes, and at $20 \mu \mathrm{M}$ cells were completely lysed releasing extracellular materials and showing OMVs. OMVs have been reported in practically all gram-negative bacteria (Jan 2017; Solé et al. 2015), including X. fastidiosa (Ionescu et al. 2014), in many cases as a response to envelope stress (McBroom and Kuehn 2007). Cell lysis was also observed in $X$. fastidiosa subsp. pauca strain DD1 but at higher peptide concentration $(100 \mu \mathrm{M})$ and to a lesser extend compared with the Temecula strain. The same cristate structure of a well-organized cell envelope was observed in DD1, but in addition, a capsule of exopolysaccharides around DD1 cells was shown. This is in agreement with the reports of exopolysaccharide secretion (fastidian gum) in other $X$. fastidiosa strains (Da Silva et al. 2001; Roper et al. 2007). Resistance to antimicrobial peptides in human pathogens has been associated to exomucopolysaccharide capsules (Joo et al. 2016). Thus, the presence of the extracellular matrix in DD1 could explain its greater tolerance to peptides compared with the other strains studied in the present work.

The maximum reduction in survivors under the effect of lytic peptides was observed at 10 to $20 \mathrm{~min}$ at all concentrations tested, which implicates a rapid lytic action of these type of peptides on $X$. fastidiosa. However, a plateau on reduction in survivors was also observed in all cases. The plateau was dependent on the peptide concentration and this is similar to what has been reported for several disinfectants against human pathogens (Ioannou et al. 2007; Lambert et al. 1999). This is because the antimicrobial compound binds to target cells and therefore is being consumed or degraded by

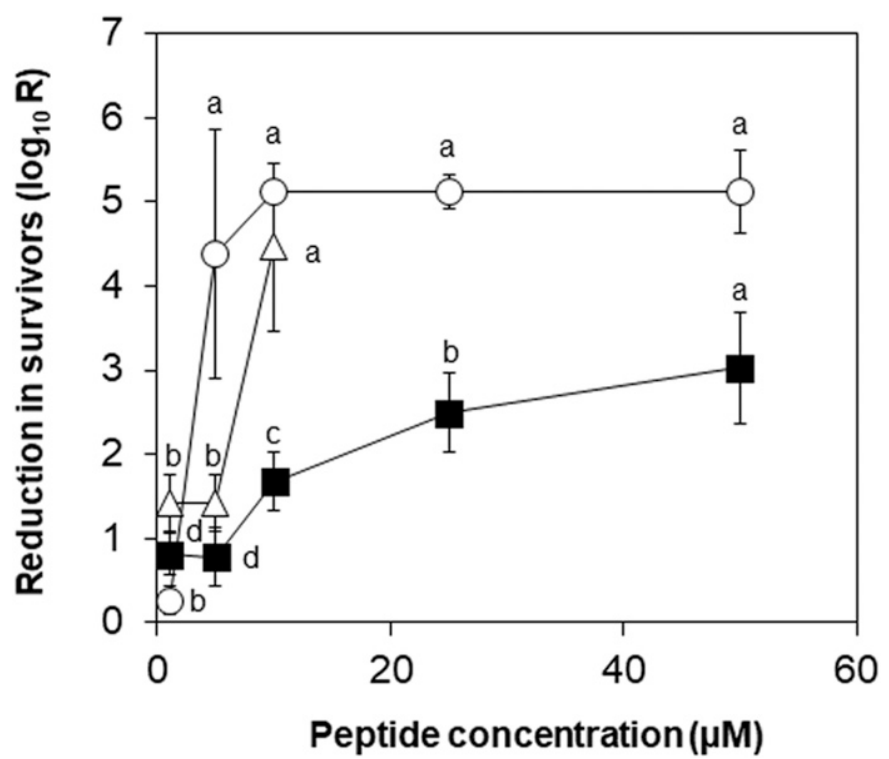

Fig. 7. Effect of the concentration of peptide BP178 on survival of Xylella fastidiosa subsp. pauca DD1 (black square), X. fastidiosa subsp. fastidiosa Temecula (white circle), and X. fastidiosa subsp. multiplex IVIA 5901.2 (white triangle) at an initial cell concentration of $10^{7} \mathrm{CFU} / \mathrm{ml}$. Values are the means of three replicates, and error bars represent the standard deviation of the mean. Different letters within the same strain indicate significant differences between peptide concentrations according to Tukey's test $(P<0.05)$.

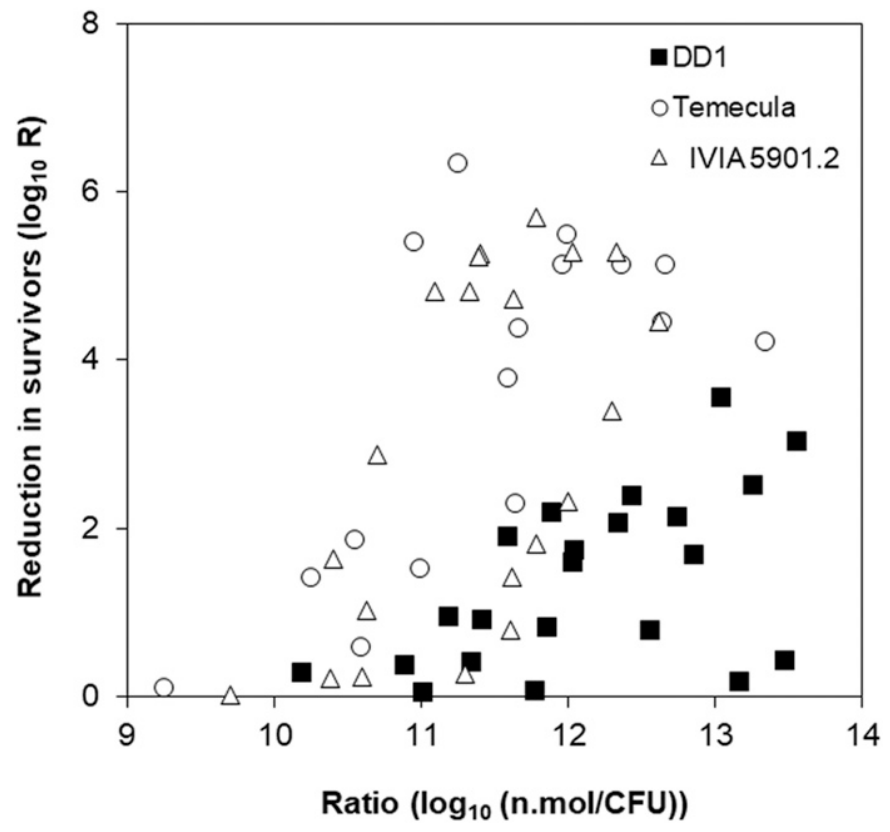

Fig. 8. Scatter plot of the reduction in survivors with the ratio of the number of molecules of peptide BP178 per cell in Xylella fastidiosa subsp. pauca DD1, $X$. fastidiosa subsp. fastidiosa Temecula, and X. fastidiosa subsp. multiplex IVIA 5901.2. Data combined from experiments shown in Figures 1, 6, and 7. Reduction in survivors was calculated at the end time points during the contact tests, performed at different cell and peptide concentrations. 
the bacterial cells during the interaction. Lambert and Johnston (2000) have considered this effect in their intrinsic quenching model of bacterial death kinetics in the presence of a disinfectant. In our study, we observed that the reduction in survivors decreased when cell concentration increased, and this fact agreed with the assumption of the abovementioned authors due to a cell quenching of the peptide.

A threshold of bactericidal action for BP178 peptide against $X$. fastidiosa, in terms of molecules per cell, is reported in the present study. We have found for the three strains of $X$. fastidiosa a threshold ratio BP178/cell of $10^{9}$ in the killing assay. Using growth inhibition assays, the minimum inhibitory concentration of BP178 against Erwinia amylovora, Pseudomonas syringae pv. syringae, and Xanthomonas axonopodis pv. vesicatoria was in the range of 2.5 to $5 \mu \mathrm{M}$ (Badosa et al. 2013). Considering these results, the threshold ratio for growth inhibition of these plant pathogenic bacteria can be estimated as $10^{7}$ molecules per cell. Although information provided by growth inhibition and killing assays is different, $X$. fastidiosa seems to be less susceptible to peptide BP178 than other plant pathogenic bacteria. Additionally, for synthetic vesicles mimicking bacterial cell membranes exposed to the peptide BP100 (a CECMEL11 peptide), it has been reported that $1.1 \times 10^{4} \mathrm{BP} 100 /$ vesicle were needed for leakage of their contents
(Manzini et al. 2014). Taking into account an average radius of the vesicles of $50 \mathrm{~nm}$, this effective dose corresponds to a ratio of $0.3 \times 10^{7} \mathrm{BP} 100 / \mu \mathrm{m}^{2}$. From the TEM observation of cells size of $X$. fastidiosa, the average surface of a cell can be calculated as $45 \mu^{2}$ (data not shown). Then, a threshold action for BP178 in $X$. fastidiosa is around $2.2 \times 10^{7} \mathrm{BP} 178 / \mu \mathrm{m}^{2}$, which is seven times the value reported for synthetic vesicles. Therefore, there is higher threshold action ratio of this lytic peptide in X. fastidiosa than in other bacteria or in synthetic membrane vesicles. The existence of a bactericidal threshold action for BP178 has implications in disease management. Under high inoculum of $X$. fastidiosa, a given dose of peptide for plant treatment could be noneffective if the ratio peptide to cells is below the threshold. For this reason, it is important to know this threshold action and adjust the treatment dose to the inoculum of the pathogen. However, this is not only an issue with the peptide but it also happens with other antimicrobials.

In addition, we reported a differential susceptibility to the BP178 peptide among a set of seven strains of $X$. fastidiosa being the subsp. pauca DD1 the most tolerant, and subsp. multiplex CFBP 8173 the most susceptible. It can be speculated that these difference could be due to changes in the cell envelope structure and composition. In fact, the species $X$. fastidiosa presents a large flexible gene pool that is described to be strain-specific, resulting in genomes of variable
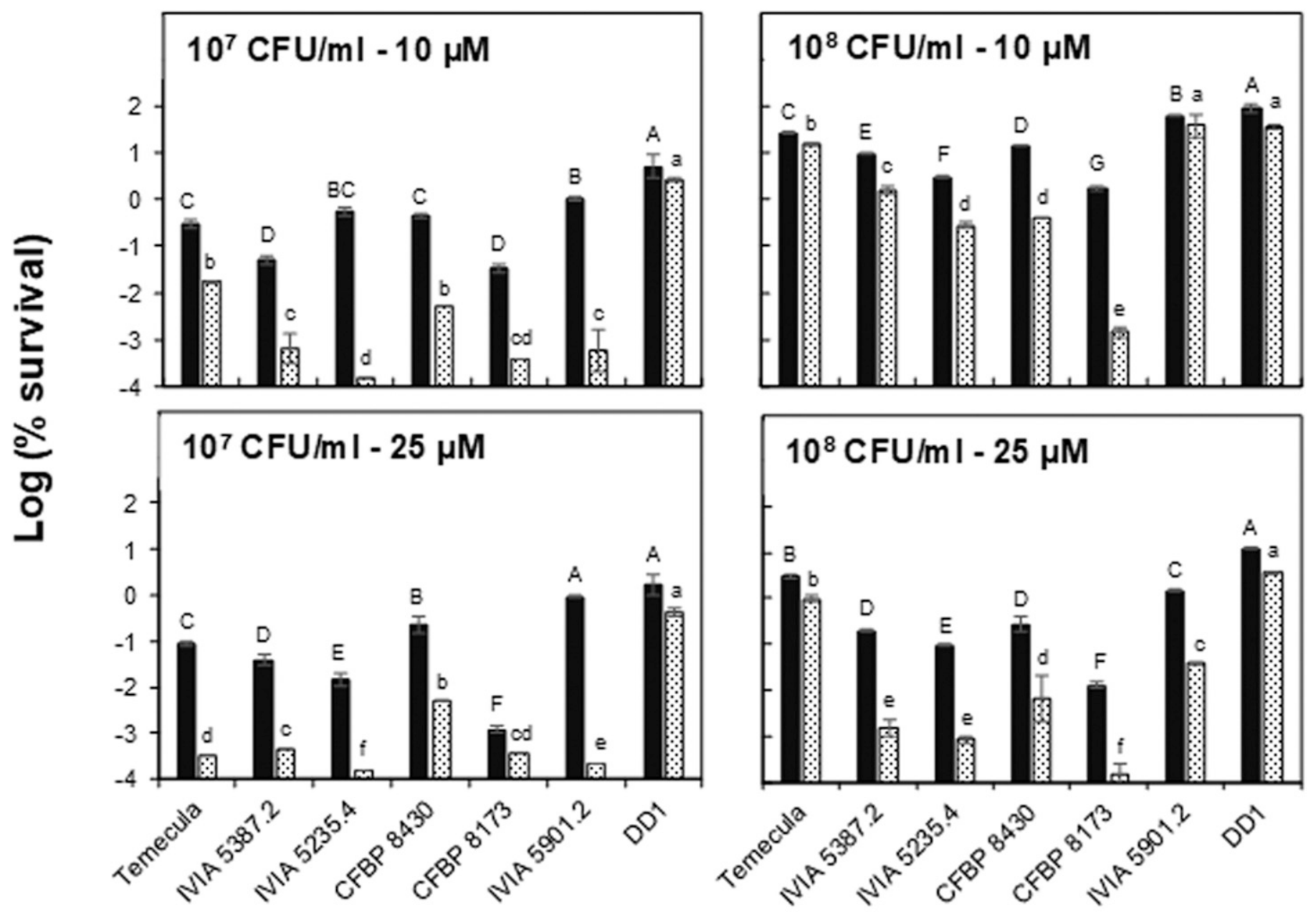

\section{$X$. fastidiosa strains}

Fig. 9. Effect of peptide BP178 on survival of seven strains of three subspecies of Xylella fastidiosa. Survival was measured as viable (v-qPCR, black columns) and culturable cells (plate counting, dotted columns). The experiments correspond to low $\left(10^{7} \mathrm{CFU} / \mathrm{ml}\right)$ and high $\left(10^{8} \mathrm{CFU} / \mathrm{ml}\right)$ cell concentration suspensions that were exposed to 10 or $25 \mu \mathrm{M}$ peptide. Values are the means of three replicates, and error bars represent the standard deviation of the mean. Capital letters correspond to comparison of viable cells survival between strains. Lowercase letters correspond to comparison of culturable cells survival between strains. Comparisons within each panel were performed according to Tukey's test $(P<0.05)$. 
sizes between strains and containing specific gene sets. Most of this genomic diversity is related with environmental response factors, such as drug-resistance enzymes or transcriptional factors, but also to variations associated with structural compounds of the cell wall and the outer membrane (Nunes et al. 2003). Particularly, a recent genomic analysis has revealed that the subspecies pauca have 175 GO terms overrepresented compared with the other subspecies, and 20 of them have been associated with the bacterial envelope, cell wall and plasma membrane (Denancé et al. 2019). Also, different levels of OMV production have been observed (Feitosa-Junior et al. 2019), which can be another key factor to explain the different susceptibility of the strains to the peptides. Further experiments with BP178 are needed to know in more detail additional mechanisms of action (e.g., possible intracellular targets) and detoxification pathways (protease degradation, sequestering by capsular structures, and detoxification with OMVs) in $X$. fastidiosa, to develop and improve strategies for the use of this peptide in disease management.

During the killing assay after the exposure to BP178, the amount of viable cells ( $\mathrm{v}-\mathrm{qPCR}$ ) was higher than of culturable cells in all strains of $X$. fastidiosa studied. The difference can be attributed to the induction of VBNC. Our finding with peptide BP178 is in agreement with the report that $X$. fastidiosa subsp. fastidiosa Temecula enters into a viable but nonculturable state under the exposure to Zn (Navarrete and De La Fuente 2014), and extends the ability to develop this stage to other strains of the subspecies multiplex and pauca. In the VBNC state, bacteria fail to grow and to produce colonies on agar media, although they remain alive (Oliver 2000). The VBNC state has been reported in other plant pathogenic bacteria like Erwinia amylovora, Ralstonia solanacearum, and Xanthomonas axonopodis pv. citri as a survival mechanism to stressful conditions (e.g., starvation and $\mathrm{Cu}$ compounds) (Del Campo et al. 2009; Grey and Steck 2001; Ordax et al. 2006). Interestingly, response of $X$. fastidiosa strains to treatment was very different in terms of VBNC levels, because in DD1 practically all viable cells were culturable. The difference could be attributed to the different performance and capacity to grow in the synthetic media that has been reported (Almeida and Purcell 2003).

Conclusions. The present study provides additional knowledge on the mechanisms of action of antimicrobials against $X$. fastidiosa, specifically of lytic synthetic antimicrobial peptides. Findings about death kinetics, dose-response relationships, and threshold action ratio, and the differential susceptibility among strains would have important consequences for managing the diseases in infected plant host strategies.

\section{ACKNOWLEDGMENTS}

We thank Ester Marco from IVIA (Spain) and Maria Saponari from CNR-IPSP (Italy) for providing X. fastidiosa strains, and Microscopy Services from the Universitat de Girona (Daniel Reyes) and Universitat Autònoma de Barcelona (Alejandro Sànchez).

\section{LITERATURE CITED}

Abdelbaqi, S., Deslouches, B., Steckbeck, J., Montelaro, R., and Reed, D. S. 2016. Novel engineered cationic antimicrobial peptides display broadspectrum activity against Francisella tularensis, Yersinia pestis and Burkholderia pseudomallei. J. Med. Microbiol. 65:188-194.

Aldrich, T. J., Rolshausen, P. E., Roper, M. C., Reader, J. M., Steinhaus, M. J., Rapicavoli, J., Vosburg, D. A., and Maloney, K. N. 2015. Radicinin from Cochliobolus sp. inhibits Xylella fastidiosa, the causal agent of Pierce's disease of grapevine. Phytochemistry 116:130-137.

Almeida, R. P. P., and Purcell, A. H. 2003. Biological traits of Xylella fastidiosa strains from grapes and almonds. Appl. Environ. Microbiol. 69: 7447-7452.

Andersen, P. C., and Brodbeck, B. V. 1989. Diurnal and temporal changes in the chemical profile of xylem exudate from Vitis rotundifolia. Physiol. Plant. 75:63-70.

Andersen, P. C., Ishida, M. L., Momol, E. A., Brodbeck, B., Leite, B., and Momol, M. T. 2004. Influence of Vitis xylem fluid and xylem fluid plus cecropin on growth of Xylella fastidiosa. Vitis 43:19-25.
Badosa, E., Ferre, R., Planas, M., Feliu, L., Besalú, E., Cabrefiga, J., Bardají, E., and Montesinos, E. 2007. A library of linear undecapeptides with bactericidal activity against phytopathogenic bacteria. Peptides 28: 2276-2285.

Badosa, E., Moiset, G., Montesinos, L., Talleda, M., Bardají, E., Feliu, L., Planas, M., and Montesinos, E. 2013. Derivatives of the antimicrobial peptide BP100 for expression in plant systems. PLoS One 8:e85515.

Coletta-Filho, H. D., and Machado, M. A. 2003. Geographical genetic structure of Xylella fastidiosa from citrus in São Paulo State, Brazil. Phytopathology 93:28-34.

Da Silva, F. R., Luiz, A., Kemper, E. L., Leite, A., and Arrudo, P. 2001. Fastidian gum: The Xylella fastidiosa exopolysaccharide possibly involved in bacterial pathogenicity. FEMS Microbiol. Lett. 203:165-171.

Davis, M. J., Purcell, A. H., and Thomson, S. V. 1980. Isolation medium for the Pierce's disease bacterium. Phytopathology 70:425-429.

De Benedictis, M., De Caroli, M., Baccelli, I., Marchi, G., Bleve, G., Gallo, A., Ranaldi, F., Falco, V., Pasquali, V., Piro, G., Mita, G., and Di Sansebasiano, G. P. 2017. Vessel occlusion in three cultivars of Olea europaea naturally exposed to Xylella fastidiosa in open field. J. Phytopathol. 165:589-594.

Del Campo, R., Russi, P., Mara, P., Mara, H., Peyrou, M., de Leon, I. P., and Gaggero, C. 2009. Xanthomonas axonopodis pv. citri enters the VBNC state after copper treatment and retains its virulence. FEMS Microbiol. Lett. 298: 143-148.

Denancé, N., Briand, M., Gaborieau, R., Gaillard, S., and Jacques, M.-A. 2019. Identification of genetic relationships and subspecies signatures in Xylella fastidiosa. BMC Genomics 20:239.

Denancé, N., Legendre, B., Briand, M., Olivier, V., de Boisseson, C., Poliakoff, F., and Jacques, M.-A. 2017. Several subspecies and sequence types are associated with the emergence of Xylella fastidiosa in natural settings in France. Plant Pathol. 66:1054-1064.

EFSA Panel on Plant Health (EFSA PLH Panel), Bragard, C., Dehnen-Schmutz, K., DiSerio, F., Gonthier, P., Jacques, M. A., Jaques Miret, J. A., et al. 2019. Effectiveness of in planta control measures for Xylella fastidiosa. EFSA J. 17: 5666.

EPPO. 2018. PM 7/24 (3) Xylella fastidiosa. EPPO Bull. 48:175-218.

Feitosa-Junior, O. R., Stefanello, E., Zainini, P. A., Nascimiento, R., Pierry, P. M., Dandeker, A. M., Lindow, S. E., and da Silva, A. M. 2019. Proteomic and metabolomic analyses of Xylella fastidiosa OMV-enriched fractions reveals association with virulence factors and signaling molecules of the DSF family. Phytopathology 109:1344-1353.

Ferré, R., Badosa, E., Feliu, L., Planas, M., Montesinos, E., and Bardají, E. 2006. Inhibition of plant pathogenic bacteria by short synthetic cecropin Amelittin hybrid peptides. Appl. Environ. Microbiol. 72:3302-3308.

Fogaça, A. C., Zaini, P. A., Wulff, N. A., da Silva, P. I., Fázio, M. A., Miranda, A., Daffre, S., and da Silva, A. M. 2010. Effects of the antimicrobial peptide gomesin on the global gene expression profile, virulence and biofilm formation of Xylella fastidiosa. FEMS Microbiol. Lett. 306:152-159.

Garcia, A. L., Torres, S. C. Z., Heredia, M., and Lopes, S. A. 2012. Citrus responses to Xylella fastidiosa infection. Plant Dis. 96:1245-1249.

Giampetruzzi, A., Velasco-Amo, M. P., Marco-Noales, E., Montes-Borrego, M., Román-Écija, M., Navarro, I., Monterde, A., Barbé, S., Almeida, R. P. P., Saldarelli, P., Saponari, M., Montilon, V., Savino, B. N., Boscia, D., and Landa, B. B. 2019. Draft genome resources of two strains ("ESVL" and "IVIA5901") of Xylella fastidiosa associated with almond leaf scorch disease in Alicante, Spain. Phytopathology 109:219-221.

Grey, B. E., and Steck, T. R. 2001. The viable but nonculturable state of Ralstonia solanacearum may be involved in long-term survival and plant infection. Appl. Environ. Microbiol. 67:3866-3872.

Güell, I., Cabrefiga, J., Badosa, E., Ferre, F., Talleda, M., Bardají, E., Planas, M., Feliu, L., and Montesinos, E. 2011. Improvement of the efficacy of linear undecapeptides against plant-pathogenic bacteria by incorporation of D-amino acids. Appl. Environ. Microbiol. 77:2667-2675.

Güell, I., Micaló, L., Cano, L., Badosa, E., Ferre, R., Montesinos, E., Bardají, E., Feliu, L., and Planas, M. 2012. Peptidotriazoles with antimicrobial activity against bacterial and fungal plant pathogens. Peptides 33:9-17.

Ioannou, C., Hanlon, G. W., and Denyer, S. P. 2007. Action of disinfectant ammonium compounds against Staphylococcus aureus. Antimicrob. Agents Chemother. 51:296-306.

Ionescu, M., Zaini, P. A., Baccari, C., Tran, S., da Silva, A. M., and Lindow, S. E. 2014. Xylella fastidiosa outer membrane vesicles modulate plant colonization by blocking attachment to surfaces. Proc. Natl. Acad. Sci. USA 111:E3910-E3918.

Jan, A. T. 2017. Outer membrane vesicles (OMVs) of Gram-negative bacteria: A perspective update. Front. Microbiol. 8:1053.

Joo, H.-S., Fu, C.-I., and Otto, M. 2016. Bacterial strategies of resistance to antimicrobial peptides. Philos. Trans. R. Soc. Lond. B Biol. Sci. 371: 20150292. 
Kacprzyk, L., Rydengård, V., Mörgelin, M., Davoudi, M., Pasupuleti, M., Malmsten, M., and Schmidtchen, A. 2007. Antimicrobial activity of histidine-rich peptides is dependent on acidic conditions. Biochim. Biophys. Acta 1768:2667-2680.

Kumari, S., Nagendran, K., Rai, A. B., Singh, B., Rao, G. P., and Bertaccini, A. 2019. Global status of phytoplasma diseases in vegetable crops. Front. Microbiol. 10:1349.

Kuzina, L. V., Miller, T. A., and Cooksey, D. A. 2006. In vitro activities of antibiotics and antimicrobial peptides against the plant pathogenic bacterium Xylella fastidiosa. Lett. Appl. Microbiol. 42:514-520.

Kyrkou, I., Pusa, T., Ellegaard-Jensen, L., Sagot, M.-F., and Hansen, L. H. 2018. Pierce's disease of grapevines: A review of control strategies and an outline of an epidemiological model. Front. Microbiol. 9:2141.

Lambert, R. J., and Johnston, M. D. 2000. Disinfection kinetics: A new hypothesis and model for the tailing of log-survivor/time curves. J. Appl. Microbiol. 88:907-913.

Lambert, R. J., Johnston, M. D., and Simons, E. A. 1999. A kinetic study of the effect of hydrogen peroxide and peracetic acid against Staphylococcus aureus and Pseudomonas aeruginosa using the Bioscreen disinfection method. J. Appl. Microbiol. 87:782-786.

Lambert, R. J. W. 2004. Evaluation of antimicrobial efficacy. Pages 345-360 in: Russell, Hugo \& Ayliffe's Principles and practice of Disinfection, Preservation \& Sterilization. A. P. Fraise, P. A. Lambert, and J.-Y. Maillard, eds. Blackwell Publishing, Hoboken, NJ.

Lee, I. H., Cho, Y., and Lehrer, R. 1997. Effects of $\mathrm{pH}$ and salinity on the antimicrobial properties of clavanins. Infect. Immun. 65:2898-2903.

Li, Z. T., and Gray, D. J. 2003. Effect of five antimicrobial peptides on the growth of Agrobacterium tumefaciens, Escherichia coli and Xylella fastidiosa. Vitis 42:95-97.

Lima, M., Machado, A., and Gubler, W. 2017. Metabolomic study of Chardonnay grapevines double stressed with Esca-associated fungi and drought. Phytopathology 107:669-680.

Manzini, M. C., Perez, K. R., Riske, K. A., Bozelli, J. C., Jr., Santos, T. L., da Silva, M. A., Saraiva, G. K., Politi, M. J., Valente, A. P., Almeida, F. C., Chaimovich, H., Rodrigues, M. A., Bemquerer, M. P., Schreier, S., and Cuccovia, I. M. 2014. Peptide:lipid ratio and membrane surface charge determine the mechanism of action of the antimicrobial peptide BP100. Conformational and functional studies. Biochim. Biophys. Acta 1838: 1985-1999.

Marcos, J. F., Muñoz, A., Pérez-Payá, E., Misra, S., and López-García, B. 2008. Identification and rational design of novel antimicrobial peptides for plant protection. Annu. Rev. Phytopathol. 46:273-301.

McBroom, A. J., and Kuehn, M. J. 2007. Release of outer membrane vesicles by Gram-negative bacteria is a novel envelope stress response. Mol. Microbiol. 63:545-558.

Monroc, S., Badosa, E., Feliu, L., Planas, M., Montesinos, E., and Bardají, E. 2006. De novo designed cyclic cationic peptides as inhibitors of plant pathogenic bacteria. Peptides 27:2567-2574.

Montesinos, E. 2007. Antimicrobial peptides and plant disease control. FEMS Microbiol. Lett. 270:1-11

Montesinos, E., Badosa, E., Cabrefiga, J., Planas, M., Feliu, L., and Bardají, E. 2012. Antimicrobial peptides for plant disease control. From discovery to application. Pages 235-261 in: Small Wonders: Peptides for Disease Control. K. Rajasekaran, J. W. Cary, J. M. Jaynes, and E. Montesinos, eds. Oxford University Press, Washington, DC.

Montesinos, L., Bundó, M., Badosa, E., San Segundo, B., Coca, M., and Montesinos, E. 2017. Production of BP178, a derivative of the synthetic antibacterial peptide BP100, in the rice seed endosperm. BMC Plant Biol. $17: 63$.

Navarrete, F., and De La Fuente, L. 2014. Response of Xylella fastidiosa to zinc: Decreased culturability, increased exopolysaccharide production, and formation of resilient biofilms under flow conditions. Appl. Environ. Microbiol. 80:1097-1107.

Ng-Choi, I., Soler, M., Güell, I., Badosa, E., Cabrefiga, J., Bardají, E., Montesinos, E., Planas, M., and Feliu, L. 2014. Antimicrobial peptides incorporating non-natural amino acids as agents for plant protection. Protein Pept. Lett. 21:357-367.

Nguyen, L. T., Haney, E. F., and Vogel, H. J. 2011. The expanding scope of antimicrobial peptide structures and their modes of action. Trends Biotechnol. 29:464-472.

Nunes, L. R., Rosato, Y. B., Muto, N. H., Yanai, G. M., da Silva, V. S., Leite, D. B., Gonçalves, E. R., de Souza, A. A., Coletta-Filho, H. D., Machado,
M. A., Lopes, S. A., and de Oliveira, R. C. 2003. Microarray analyses of Xylella fastidiosa provide evidence of coordinated transcription control of laterally transferred elements. Genome Res. 13:570-578.

Oliver, J. D. 2000. The public health significance of viable but nonculturable bacteria. Pages 277-300 in: Nonculturable Microorganisms in the Environment. R. R. Colwell and D. Jay Grimes, eds. ASM Press, Washington, DC.

Olmo, D., Nieto, A., Adrover, F., Urbano, A., Beidas, O., Juan, A., Marco-Noales, E., López, M. M., Montes Borrego, M., Navas Cortés, J. A., and Landa, B. B. 2017. First detection of Xylella fastidiosa infecting cherry (Prunus avium) and Polygala myrtifolia plants, in Mallorca Island, Spain. Plant Dis. 101:1820.

Ordax, M., Marco-Noales, E., López, M. M., and Biosca, E. G. 2006. Survival strategy of Erwinia amylovora against copper: Induction of the viable-butnonculturable state. Appl. Environ. Microbiol. 72:3482-3488.

Pini, A., Giuliani, A., Falciani, C., Runci, Y., Ricci, C., Lelli, B., Malossi, M., Neri, P., Rossolini, G. M., and Bracci, L. 2005. Antimicrobial activity of novel dendrimeric peptides obtained by phage display selection and rational modification. Antimicrob. Agents Chemother. 49:2665-2672.

Purcell, A. 2013. Paradigms: Examples from the bacterium Xylella fastidiosa. Annu. Rev. Phytopathol. 51:339-356.

Reynolds, E. S. 1963. The use of lead citrate at high $\mathrm{pH}$ as an electron-opaque staining electron microscopy. J. Cell Biol. 17:208-212.

Rodrigues, J. L., Silva-Steinco, M. E., Gomes, J. E., Lopes, J. R., and Tsai, S. M. 2003. Detection and diversity assessment of Xylella fastidiosa in field-collected plant and insect samples by using 16S rRNA and gyrB sequences. Appl. Environ. Microbiol. 69:4249-4255.

Roper, M. C., Carl, L., Lavbitch, J. M., and Kirkpatrick, B. C. 2007. Detection and visualization of an exopolysaccharide produced by Xylella fastidiosa in vitro and in planta. Appl. Environ. Microbiol. 73:7252-7258.

Rufo, R., Batlle, A., Camprubi, A., Montesinos, E., and Calvet, C. 2017. Control of rubus stunt and stolbur diseases in Madagascar periwinkle with mycorrhizae and a synthetic antibacterial peptide. Plant Pathol. 66:551-558.

Russell, A. D., Hugo, W. D., and Ayliffe, G. A. J., eds. 1982. Principles and Practice of Disinfection, Preservation and Sterilization. Blackwell Science, Hoboken, NJ.

Saponari, M., Boscia, D., Altamura, G., Loconsole, G., Zicca, S., D’Attoma, G., Morelli, M., Palmisano, F., Saponari, A., Tavano, D., Savino, V. N., Dongiovanni, C., and Martelli, G. P. 2017. Isolation and pathogenicity of Xylella fastidiosa associated to the olive quick decline syndrome in southern Italy. Sci. Rep. 7:17723.

Saponari, M., Boscia, D., Nigro, F., and Martelli, G. P. 2013. Identification of DNA sequences related to Xylella fastidiosa in oleander, almond and olive trees exhibiting leaf scorch symptoms in Apulia (Southern Italy). J. Plant Pathol. 95:668.

Saponari, M., Giampetruzzi, A., Loconsole, G., Boscia, D., and Saldarelli, P. 2019. Xylella fastidiosa in olive in Apulia: Where we stand. Phytopathology 109:175-186.

Schaad, N. W., Postnikova, C., Lacy, G., M'Barek, F., and Chang, C. J. 2004. Xylella fastidiosa subspecies: X. fastidiosa subsp. fastidiosa, subsp. nov., $X$. fastidiosa subsp. multiplex subsp. nov., and $X$. fastidiosa subsp. pauca subsp. nov. Syst. Appl. Microbiol. 27:290-300.

Schwab, U., Gilligan, P., Jaynes, J., and Henke, D. 1999. In vitro activities of designed antimicrobial peptides against multidrug-resistant cystic fibrosis pathogens. Antimicrob. Agents Chemother. 43:1435-1440.

Sicard, A., Zeilinger, A. R., Mathieu, M., Schartel, T. E., Beal, D. J., Daugherty, M. P., and Almeida, R. P. P. 2018. Xylella fastidiosa: Insights into an emerging plant pathogen. Annu. Rev. Phytopathol. 56:181-202.

Solé, M., Scheibner, F., Hoffmeister, A. K., Hartmann, N., Hause, G., Rother, A., Jordan, M., Lautier, M., Arlat, M., and Büttner, D. 2015. Xanthomonas campestris pv. vesicatoria secretes proteases and xylanases via the Xps type II secretion system and outer membrane vesicles. J. Bacteriol. 197: 2879-2893.

Tyree, M., and Zimmermann, M., eds. 2002. Xylem Structure and the Ascent of Sap. Springer, Berlin, Germany.

Vilà, S., Badosa, E., Montesinos, E., Planas, M., and Feliu, L. 2016. Synthetic cyclolipopeptides selective against microbial, plant and animal cell targets by incorporation of D-amino acids or histidine. PLoS One 11:e0151639.

Wang, N., Pierson, E. A., Setubal, J. C., Xu, J., Levy, J. G., Zhang, Y., Li, J., Rangel, L. T., and Martins, J., Jr. 2017. The Candidatus Liberibacter-host interface: Insights into pathogenesis mechanisms and disease control. Annu. Rev. Phytopathol. 55:20.1-20.32. 